\title{
Protection against the Neurotoxic Effects of $\beta$-Amyloid Peptide on Cultured Neuronal Cells by Lovastatin Involves Elevated Expression of a7 Nicotinic Acetylcholine Receptors and Activating Phosphorylation of Protein Kinases
}



From the Department of Pathology, * Affiliated Hospital, the Department of Microbiology, ${ }^{\dagger}$ and the Key Laboratories of Medical Microbiology and Parasitology, ${ }^{\ddagger}$ Medical Molecular Biology, ${ }^{\circledR}$ and Endemic and Ethnic Diseases of the Ministry of Education, ${ }^{\S}$ Guizhou Medical University, Guiyang, People's Republic of China

\author{
Accepted for publication \\ November 28, 2017. \\ Address correspondence to \\ Zhi-Zhong Guan, Ph.D., \\ Department of Pathology at the \\ Affiliated Hospital of Guizhou \\ Medical University, Guiyang \\ 550004, Guizhou, People's \\ Republic of China. E-mail: \\ zzg@gmc.edu.cn.
}

\begin{abstract}
The treatment of neurodegenerative diseases with statins has drawn increasing attention, but the related molecular mechanisms remain elusive. To examine the pleiotropic cholesterol-independent effects of statins in connection with the treatment of Alzheimer disease, we probed the influence of lovastatin on the metabolism of amyloid precursor protein (APP), expression of nicotinic acetylcholine receptors ( $n A C h R s)$, and activity of mitogen-activated protein kinase (MAPK) in primary cultured neurons and SH-SY5Y cells overexpressing human APP670/671. Lovastatin attenuated the neurotoxic effects of $\beta$-amyloid peptide $(A \beta)$ and affected the metabolism of APP, reducing levels of $A \beta 1$ to $A \beta 42$ and $\beta$-site amyloid precursor protein-cleaving enzyme 1 ; enhancing those of $\alpha A P P$, disintegrin metalloproteinase domain-containing protein 10 , and $\beta$-site amyloid precursor protein-cleaving enzyme 2; and up-regulating expression of $\alpha 7 \mathrm{nAChR}$ and stimulating phosphorylation of extracellular signalregulated kinase (ERK)1/2. Interestingly, methyllycaconitine, an antagonist of $\alpha 7 \mathrm{nAChR}$, attenuated this effect on $\alpha$ APP, but not on phospho-ERK1/2; whereas U0126, an inhibitor of MAPK/ERK kinase/ ERK, blocked both the elevated expression of $\alpha 7 \mathrm{nAChR}$ and enhanced secretion of $\alpha \mathrm{APP}$. Our findings indicate that lovastatin up-regulates expression of $\alpha 7 \mathrm{nAChR}$ by a mechanism involving activation of the MAPK/ERK pathway, which may result in diminished production of A $\beta$. (Am J Pathol 2018, 188: 1081-1093; https://doi.org/10.1016/j.ajpath.2017.11.020)
\end{abstract}

Alzheimer disease (AD), the most common cause of dementia in the elderly, is a progressive neurodegenerative condition characterized by a large number of extracellular senile plaques composed of $\beta$-amyloid peptide $(A \beta)$, intracellular neurofibrillary tangles that consist of hyperphosphorylated tau protein, and selective loss of neurons in the brain. ${ }^{1}$ The 39 to 43 amino acid residues of $\mathrm{A} \beta$ are derived from the transmembrane amyloid precursor protein (APP), ${ }^{2}$ which can be processed in two distinct ways: the nonamyloidogenic pathway involves $\alpha$-secretase-mediated cleavage and yields the soluble $\alpha$-form of secreted APP ( $\alpha$ APP) that possesses neurotrophic and neuroprotective properties, ${ }^{3}$ whereas the amyloidogenic pathway involves $\beta$-secretase-mediated cleavage to produce nonsoluble and toxic $A \beta$.

The number of persons who have AD is increasing, and the need for effective pharmacologic treatment is becoming more and more pronounced. ${ }^{4}$ Both epidemiologic and experimental studies indicate that treatment with statins reduces the risk of

Supported Chinese National Natural Science Foundation grants 81760571 and 81260173; Foundation of the Ministry of Education of P.R. China grant IRT13058; and Scientific Foundations in Guizhou Province of China grants [2014]06, [2014]4010, and [2014]6008.

Disclosures: None declared. 
developing AD. ${ }^{5}$ Statins are important therapeutic agents against hypercholesterolemia, reducing plasma cholesterol levels by inhibiting 3-hydroxy-3-methylglutaryl-coenzyme A reductase, the rate-limiting enzyme in cholesterol biosynthesis. ${ }^{6}$ It has been reported that statins also attenuate generation of $A \beta$ by promoting nonamyloidogenic processing of $\mathrm{APP}^{7}$ and/or by exerting antiamyloidogenic effects. ${ }^{8-10}$ Moreover, statins exert numerous other effects, including suppression of inflammatory responses; protection of neurons from excitotoxins, apoptosis, and oxidative stress, and promotion of synaptogenesis, ${ }^{11,12}$ all of which may be independent of its inhibition of cholesterol synthesis. ${ }^{13,14}$

However, protection against AD by statins is controversial. In experimental models of $\mathrm{AD}$, statins reduce the production of $\mathrm{A} \beta$ by disrupting secretase and reducing neuroinflammation, and epidemiology indicates that these agents may lower the incidence of AD. ${ }^{15}$ However, in neither of the two randomized trials was any reduction in the occurrence of $\mathrm{AD}$ in patients treated with statins compared with placebo observed. ${ }^{16}$ Thus, the potential effects of statins on the molecular pathologic processes underlying $\mathrm{AD}$ remain unclear.

Previously, we reported that lovastatin enhances the production of $\alpha$ APPs by cultured neurons and astrocytes by stimulating the expression of $\alpha 7$ nicotinic acetylcholine receptors (nAChRs) by a cholesterol-independent mechanism. ${ }^{17-19}$ The nAChRs, members of a super family of ligand-gated ion channels, mediate a variety of important physiological functions. In the central nervous system, the $\alpha$ $(\alpha 2-\alpha 10)$ and $\beta(\beta 2-\beta 4)$ subunits combine to form both heteropentameric and homopentameric neuronal nAChRs. ${ }^{20}$ Among these, $\alpha 7$ and $\alpha 4 \beta 2$ are the main subtypes in the brains of humans and animals, participating, in response to acetylcholine, in a wide range of brain functions, including cognitive enhancement. The expression of nAChRs in the brains of patients with $\mathrm{AD}$ is reduced. ${ }^{21,22}$ However, the mechanisms underlying the up-regulation of $\alpha 7 \mathrm{nAChRs}$ by statins and subsequent increase in $\alpha$ APPs remain elusive.

The mitogen-activated serine-threonine protein kinases (MAPKs) include c-Jun $\mathrm{NH}_{2}$-terminal kinase (JNK), p38 MAPK, and extracellular signal-regulated kinase (ERK), which regulate a variety of cellular activities, including proliferation, differentiation, apoptosis, survival, inflammation, and innate immunity. ${ }^{23,24}$ These kinases also play key roles in the pathogenesis of various diseases, including cancer and neurodegenerative disorder, such as $\mathrm{AD} .{ }^{25}$ For example, chronically elevated levels of $A \beta$ have been reported to lead to dysregulation of hippocampal ERK MAPK both in vitro and in vivo, ${ }^{26,27}$ whereas oxidative stress induced by $\mathrm{A} \beta$ has been claimed to result in activation of p38 MAPK and consequent hyperphosphorylation of tau. ${ }^{28}$

Recent observations indicate that signaling through pathways involving MAPKs may be involved in the effects of statins. For example, atorvastatin prevents the synaptotoxicity and memory dysfunction induced by oligomers of $A \beta$ by a 38 MAPK-dependent pathway. ${ }^{29}$ Moreover, rescue of longterm potentiation induction by simvastatin can be blocked by antagonists of $\alpha 7 \mathrm{nAChRs}$ or of MAPK/ERK kinase (MEK). ${ }^{30}$ One investigation demonstrated that $\mathrm{A} \beta$ activates the MAPK/ERK cascade in the hippocampus by $\alpha 7$ nAChRs. ${ }^{26}$ However, others have been unable to confirm the beneficial effects of statins on patients with $\mathrm{AD},{ }^{16}$ and additional prospective randomized clinical trials designed to resolve these discrepancies are required. ${ }^{31}$

Here, we exposed both primary hippocampal neurons from the brains of postnatal rats and SH-SY5Y cells expressing high levels of APP (SH-SY5Y/APP ${ }_{\mathrm{SWE}}$ cells) to either lovastatin at levels that do not influence cholesterol biosynthesis or/and to an inhibitor of MEK1/2, ERK1/2 siRNA, or antagonist of $\alpha 7 \mathrm{nAChR}$. Subsequently, we examined the neurotoxicity of $A \beta$, metabolic processing of APP, expression of nAChRs, and activity of the MAPK pathway in these cells. The goal was to further elucidate the mechanisms underlying enhancement of $\mathrm{A} \beta$ clearance by lovastatin, involving stimulation of $\alpha 7 \mathrm{nAChR}$ and MAPK/ERK.

\section{Materials and Methods}

\section{Materials}

Lovastatin, poly-L-lysine hydrobromide, the Cholesterol Quantitation Kit (MAK043), the Lipid Peroxidation Assay Kit for detection of malondialdehyde (MDA), the Superoxide Dismutase (SOD) Determination Kit, and all other general chemicals were purchased from Sigma-Aldrich (St. Louis, MO). The Cell Counting Kit-8 (Dojindo Molecular Technologies, Inc., Dojindo, Japan); Cruz Marker Molecular Weight Standards (SC2035) conjugated with horseradish peroxidase (Santa Cruz Biotechnology Inc., Santa Cruz, CA), U0126 (an inhibitor of MEK1/2), and the Protease/Phosphatase Inhibitor Cocktail (Cell Signaling, Danvers, MA); the DC Protein Assay kit, cDNA synthesis kit, TRIzol reagent, Mer-PER Eukaryotic Membrane Protein Extraction Reagent Kit, prestained protein ladder, and LDH (lactate dehydrogenase) Cytotoxicity Assay Kit (Thermo Fisher Scientific, Waltham, MA); methyllycaconitine (MLA; Tocris Bioscience, Bristol, UK); Neurobasal-A Medium, Hibernate-E Medium, B-27 Serum-Free supplement, GlutaMAX Supplement, NuPAGE Novex 4-12\% Bis-Tris Gel, NuPAGE LDS Sample buffer, and NuPAGE Reducing agent, $\beta$-Amyloid(1 to 42) enzyme-linked immunosorbent assay (ELISA) kits (99-0064), mouse A 342 ELISA kit (KMB3441), and SYBR green master and Fugene 6 Transfection Reagent (Roche, Basel, Switzerland); ECL (enhanced chemiluminescence) Plus reagent (Merck Millipore, Darnstadt, Germany); and Hyper Performance Chemiluminescence film (Amersham, Uppsala, Sweden) were purchased from the sources indicated. The antibodies used are listed in Table 1.

\section{Cell Cultures}

Primary hippocampal neurons were prepared from the brains of neonatal Sprague-Dawley rats according to a 
Table 1 Antibodies Used in This Study

\begin{tabular}{|c|c|c|c|c|}
\hline Antibody & Host & Specificity & Source & Catalog no. \\
\hline Anti- $\alpha 7$ nAChR & r & $\mathrm{T}, \alpha 7 \mathrm{nAChR}$ & $\begin{array}{l}\text { Santa Cruz Biotechnology } \\
\text { Inc., Santa Cruz, CA }\end{array}$ & SC58607 \\
\hline Anti- $\alpha 4$ nAChR & r & $\mathrm{T}, \alpha 4 \mathrm{nAChR}$ & Santa Cruz Biotechnology Inc. & SC65862 \\
\hline Anti- $\beta 2$ nAChR & r & $\mathrm{T}, \beta 2 \mathrm{nAChR}$ & Santa Cruz Biotechnology Inc. & SC58596 \\
\hline Anti- $\alpha 3$ nAChR & g & $\mathrm{T}, \alpha 3 \mathrm{nAChR}$ & Santa Cruz Biotechnology Inc. & SC1771 \\
\hline Anti-A $\beta 6 \mathrm{E} 10$ & $\mathrm{~m}$ & $\begin{array}{l}\mathrm{T} \text {, amino acid } \\
\quad \text { residue } 1-16 \text { of } \beta \text {-amyloid }\end{array}$ & Covance, Princeton, NJ & SIG-39321 \\
\hline Anti-BACE1 & $\mathrm{m}$ & T, BACE1 & GeneTex & GTX78908 \\
\hline Anti-ADAM10 & ra & T, ADAM10 & Abcam, Cambridge, MA & ab124695 \\
\hline Anti-phospho-p44/42 & ra & P, phosphorylated p44/42 MAPK & Cell Signaling, Danvers, MA & 4370 \\
\hline Anti-p44/42 & ra & T, p44/42 MAPK & Cell Signaling & 4695 \\
\hline Anti-phospho-SAPK/JNK & ra & P, phosphorylated SAPK/JNK MAPK & Cell Signaling & 4668 \\
\hline Anti-pre-APP A4(22C11) & $\mathrm{m}$ & $\begin{array}{l}\text { T, N-terminal } \\
\text { epitope on the pre-A4 }\end{array}$ & Merck Millipore & MAB348 \\
\hline Anti-GFAP & ra & T, GFAP & Dako, Carpinteria, CA & Z0334 \\
\hline Anti- $\beta$-actin & ra & $\mathrm{T}, \beta$-actin & Abmart, Berkeley Heights, NJ & P30002 \\
\hline Anti-rabbit IgG & $g$ & $\mathrm{~T}$, rabbit $\mathrm{IgG}$ & Cell Signaling & 7074 \\
\hline $\begin{array}{l}\text { Anti-mouse IgG } \\
\text { labeled with cyanine } 3\end{array}$ & g & $\mathrm{T}$, mouse IgG & Thermo Scientific, Waltham, MA & A10521 \\
\hline $\begin{array}{l}\text { Anti-rabbit IgG } \\
\text { labeled with } 488\end{array}$ & g & T, rabbit IgG & Thermo Scientific & A11034 \\
\hline Anti-goat IgG & $d$ & T, goat IgG & Santa Cruz Biotechnology Inc. & SC2020 \\
\hline Anti-mouse IgG & $\mathrm{g}$ & $\mathrm{T}$, mouse $\mathrm{IgG}$ & Santa Cruz Biotechnology Inc. & SC2005 \\
\hline
\end{tabular}

$A \beta, \beta$-amyloid peptide; ADAM, disintegrin metalloproteinase domain-containing protein; APP, amyloid precursor protein; BACE, $\beta$-site amyloid precursor protein-cleaving enzyme; d, donkey; g, goat; GFAP, glial fibrillary acidic protein; JNK, c-Jun $\mathrm{NH}_{2}$-terminal kinase; m, mouse; MAPK, mitogen-activated serinethreonine protein kinase; $n A C h R$, nicotinic acetylcholine receptor; $P$, phosphorylated; $r$, rat; ra, rabbit; SAPK, stress-activated protein kinase; $T$, total.

published procedure ${ }^{32,33}$ with slight modifications. In brief, the hippocampus was dissected from the brains of neonatal rats within 2 to 3 minutes after sacrifice and then maintained in Hibernate A Medium on ice. After removing the meninges and vessels, the hippocampus was washed three times with Hank's buffered saline solution and then digested with $0.25 \%$ trypsin for 10 minutes at $37^{\circ} \mathrm{C}$. This digestion was terminated with Dulbecco's modified Eagle's medium containing $10 \%$ fetal bovine serum.
After washing two more times with Hank's buffer, the digested tissue was resuspended in $2 \mathrm{~mL}$ of Neurobasal/B27 complete medium (Neurobasal A Medium containing 2\% B27, $1 \%$ GlutaMAX Supplement, $100 \mathrm{U} / \mathrm{mL}$ penicillin, and $100 \mathrm{mg} /$ $\mathrm{mL}$ streptomycin) and disassociated with fire-polished glass pipettes. The upper single-cell suspension thus obtained was transferred into a new tube, and the cells placed onto 96-, 24-, 12-, or 6-well Poly-L-Lysine-coated plates at a density of approximately $5.0 \times 10^{4}$ cells $/ \mathrm{cm}^{2}$ and thereafter maintained

Table 2 Primers Used for Amplification of cDNA Encoding Different Subunits of Rat nAChRs or Cyclophilin (an Internal Control)

\begin{tabular}{|c|c|c|c|}
\hline nAChR subunit & $5^{\prime}-3^{\prime}$ Nucleotide sequence of the primer & Size, bp & $T_{\mathrm{m}},{ }^{\circ} \mathrm{C}$ \\
\hline \multirow[t]{2}{*}{$\beta 2$} & F: 5'-AGGGCGAGGCGGTTTTCTT-3' & 180 & 55 \\
\hline & $\mathrm{R}: 5^{\prime}-\mathrm{GCGTACGCCATCCACTGCT-3^{ \prime }}$ & & \\
\hline$\alpha 3$ & R: 5'-GGCAACGTACTTCCAATCATC-3' & & \\
\hline \multirow[t]{2}{*}{$\alpha 4$} & F: 5'-TAATACGACTCACTATAGGGAGGGCGAGGCCGGCATCTTGAGT-3' & 274 & 60 \\
\hline & R: $5^{\prime}-$ GCTGGGCACATGCTGGACAC-3' & & \\
\hline \multirow[t]{2}{*}{$C P$} & F: 5'-GACAAGGTCCCAAAGACAGC- $3^{\prime}$ & 235 & $\mathrm{C}$ \\
\hline & R: 5'-GTCCAGCATTTGCCATGGAC-3' & & \\
\hline
\end{tabular}

$\mathrm{CP}$, cyclophilin; F, Forward; $\mathrm{R}$, Reverse; $T_{\mathrm{m}}$, melting temperature. 



D

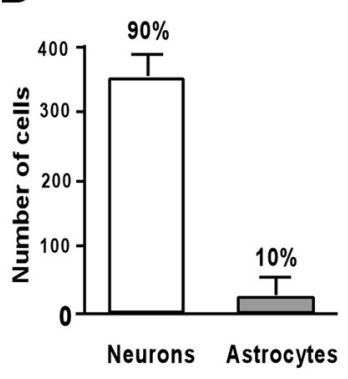

$E$

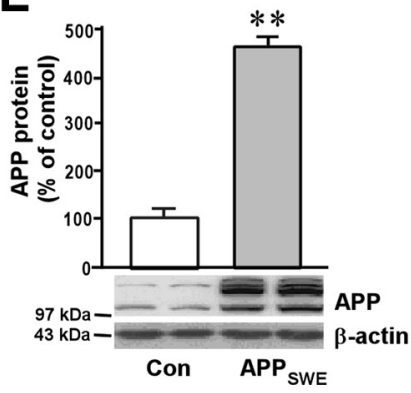

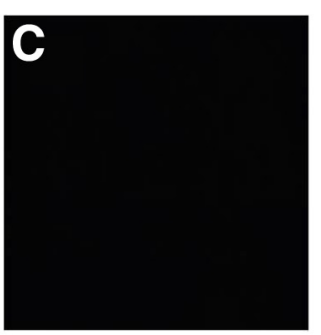

$\mathbf{F}$

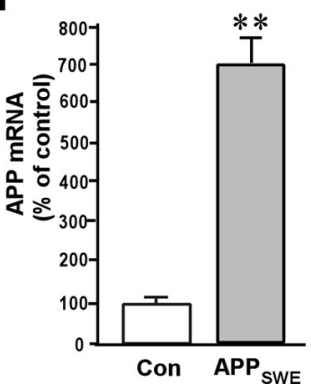

Figure 1 Identification of primary cultured

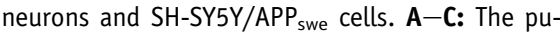
rity of neurons was determined under high magnification by counting the numbers of neurons and astrocytes that were double immunofluorescent-labeled with mouse anti-NeuN antibody and anti-mouse IgG labeled with cyanine $3(\mathbf{A})$, and with rabbit anti-glial fibrillary acidic protein antibody and anti-rabbit IgG labeled with 488 (B), along with a negative control (C) performed without primary antibodies. D: The percentage of neurons was approximately $90 \%$. E and F: Western blot analysis with monoclonal antibody 6 E10 (E) or RT-PCR (F) for amyloid precursor protein (APP) in SH-SY5Y cells transfected with pcDNA3 vectors with $\left(\mathrm{APP}_{\text {swe }}\right)$ or without (con) human APP670/671. Representative Western blot analyses are depicted below panel E. Data are expressed as means \pm SD. $n=5 .{ }^{* *} P<0.01$ versus control. under a humidified atmosphere containing $5 \% \mathrm{CO}_{2}$ at $37^{\circ} \mathrm{C}$, with replacement of half of the medium every 3 days. The purity of primary neurons was assessed by counting these cells and astrocytes after immunofluorescence staining with mouse antiNeuN antibody (dilution 1:50) and anti-mouse IgG labeled with cyanine 3 (red; dilution 1:200), as well as with rabbit anti-glial fibrillary acidic protein antibody (dilution 1:300) and anti-rabbit IgG labeled with 488 (green; dilution 1:200). After 10 days of incubation, the medium was replaced with neurobasal medium lacking B27, and the neurons were then subjected to various treatments. All of the experiments described here were preapproved by the regional ethical committee of Guizhou Province, China.

SH-SY5Y neuroblastoma cells (German Collection of Microorganisms and Cell Cultures, Braunschweig, Germany) were routinely cultured in Dulbecco's modified Eagle's medium containing $15 \%$ heat-inactivated fetal bovine serum and supplemented with $100 \mathrm{U} / \mathrm{mL}$ penicillin and streptomycin under a humidified atmosphere containing $5 \% \mathrm{CO}_{2}$ at $37^{\circ} \mathrm{C}$. At $80 \%$ to $90 \%$ confluency, these cells were transfected on 6well plates with empty pcDNA 3.0 plasmids or the same plasmid carrying the APP gene with the Swedish mutation at residues 670/671, ${ }^{34}$ using Fugene 6 (Roche) in accordance with the supplier's protocol. These transfected cells were harvested after 72 hours. This transfection was performed in triplicate in each of at least five independent experiments. The levels of APP mRNA and protein were analyzed by RT-PCR and Western blot analyses, respectively. ${ }^{34}$

Treatments of Cultured Cells with Lovastatin and/or an Inhibitor of ERK or Antagonist of $\alpha 7$ nAChR

The primary neurons and SH-SY5Y/APP ${ }_{\mathrm{SWE}}$ cells were seeded onto 6-, 12-, 24-, and 96-well plates and after subconfluent monolayers were attained B27 or serum was withdrawn from the culture medium for 2 and 12 hours, respectively, before treatment. Suitable concentrations and times for treatment were determined by exposing them to different concentrations of lovastatin $(0.01$ to $1 \mu \mathrm{mol} / \mathrm{L})$ for various periods in starvation media and then testing for toxicity and viability with the LDH Cytotoxicity Assay Kit and Cell Counting Kit-8, respectively. In accordance with the manufactures' protocols, Cell Counting Kit- 8 solution (10 $\mu \mathrm{L} /$ well) or LDH mixture reagent ( $50 \mu \mathrm{L} /$ well) was added to the cultures or medium $(50 \mu \mathrm{L})$ separately, followed by incubation for 1 to 4 hours at $37^{\circ} \mathrm{C}$ or 30 minutes at room temperature, and then determination of absorption at 450 $\mathrm{nm}^{35}$ or at $490 \mathrm{~nm}$ and $680 \mathrm{~nm}$, respectively.

In other experiments, $10 \mu \mathrm{mol} / \mathrm{L}$ U0126 (an inhibitor of MAPK/ERK) or $10 \mu \mathrm{mol} / \mathrm{L}$ MLA (antagonist of $\alpha 7$ nAChR) was added to the cell cultures 2 hours before lovastatin. Thereafter, the cells were harvested at various time points and their lysates were subjected to further analysis.

\section{Analysis of Cholesterol Content}

Cholesterol content was assayed with the Cholesterol Quantitation Kit. In brief, cholesterol was extracted from neurons with $200 \mu \mathrm{L}$ of chloroform/isopropanol/IGEPAL CA-630 (7:11:0.1) in a microhomogenizer, and the resulting mixture was centrifuged at $13,000 \times g$ for 10 minutes. The organic phase was transferred to a new tube and then dried under air at $50^{\circ} \mathrm{C}$ and under vacuum for 30 minutes. Thereafter, the dried lipids were dissolved in Cholesterol Assay Buffer, and the mixture was mixed with a vortex mixer until homogeneous. Finally, cholesterol was quantified with the appropriate reagents and compared with a standard curve. 
A

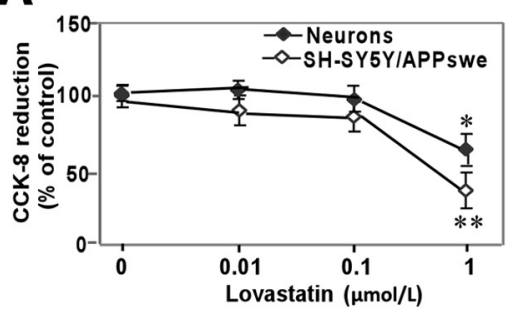

C

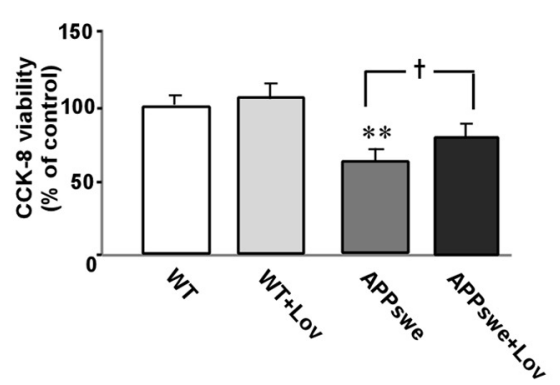

B

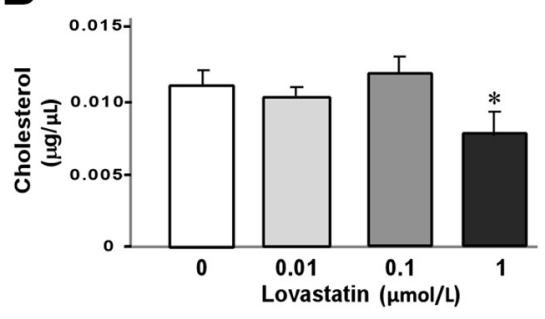

D

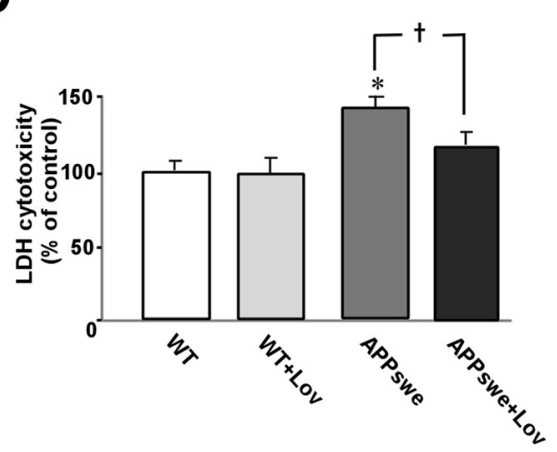

E

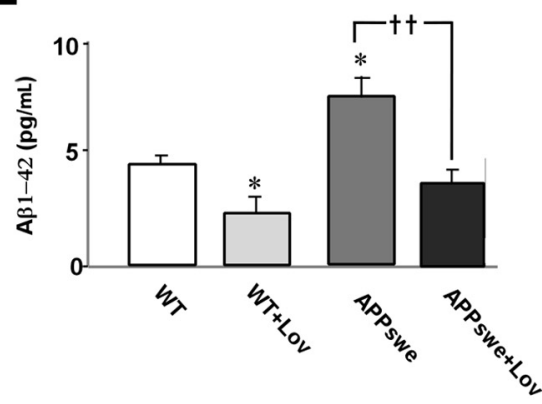

Figure 2 Cytotoxicity and the level of cholesterol and $\beta$-amyloid peptide $(A \beta) 1$ to $A \beta 42$ in the cultured cells. $\mathbf{A}-\mathbf{E}$ : Cytotoxicity (A) and the level of cholesterol (B) in primary neurons treated with $0.01,0.1$, or $1 \mu \mathrm{mol} / \mathrm{L}$ lovastatin (Lov); cell viability (C and D) and the level of AB1 to AB42 (E) in SH-SY5Y/

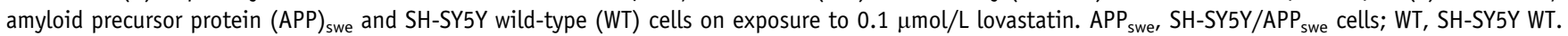
Data are expressed as means \pm SD. $n=5 .{ }^{*} P<0.05,{ }^{* *} P<0.01$ versus untreated cells ( 0 or WT); ${ }^{\dagger} P<0.05,{ }^{\dagger \dagger} P<0.01$ versus SH-SY5Y/APP swe cells, as determined by analysis of variance with the $U$-test. $\mathrm{LDH}$, lactate dehydrogenase.

\section{Determination of the Activity of SOD and Content of MDA}

SOD was assayed with the SOD Determination Kit-WST. In brief, after homogenization of the neurons in the lysis buffer on ice and centrifugation at $13,000 \times g$ for 10 minutes to remove insoluble material, an aliquot of the supernatant, the assay solution, and water-soluble tetrazolium buffer were added in the order specified by the instructions. After incubation at $37^{\circ} \mathrm{C}$ for 20 minutes, the absorbance at 450 $\mathrm{nm}$ was determined with a microplate reader, and inhibition of SOD activity (\%) calculated.

MDA, a major product of lipid peroxidation, was quantified as thiobarbituric acid-reactive substance with the use of the Lipid Peroxidation Assay Kit. In brief, $200 \mu \mathrm{L}$ of the supernatant prepared as described above was mixed with $600 \mu \mathrm{L}$ of the thiobarbituric acid-reactive substance solution in a microcentrifuge tube. This mixture was incubated at $95^{\circ} \mathrm{C}$ for 60 minutes and subsequently cooled to room temperature in an ice bath for 10 minutes. Finally, $200 \mu \mathrm{L}$ was inserted by pipette into each well of a 96-well plate, and the absorbance at $532 \mathrm{~nm}$ measured.
Quantification of the Levels of $\alpha 7, \alpha 4, \alpha 3$, and $\beta 2$ nAChR Protein and mRNA by Western Blot Analysis and Real-Time PCR, Respectively

The levels of $\alpha 7, \alpha 4, \alpha 3$, and $\beta 2 \mathrm{nAChR}$ protein were quantitated by Western blot analysis as described previously. ${ }^{17,21}$ In brief, membrane protein was extracted from cultured cells with the Eukaryotic Membrane Protein Extraction Reagent Kit and quantified with the DC Protein Assay kit. Equal aliquots $(30 \mu \mathrm{g} / \mathrm{well})$ of the dissolved membrane protein were loaded, separated by $10 \%$ SDSPAGE, and then blotted onto polyvinylidene difluoride (PVDF) membranes. These membranes were then incubated with monoclonal or polyclonal anti- $\alpha 7,-\alpha 4,-\alpha 3$, or $-\beta 2$ antibodies $(0.25 \mathrm{mg} / \mathrm{mL}$ in each case) for 120 minutes and, after washing, with horseradish peroxidase-conjugated anti-rat or -goat $\mathrm{IgG}(0.04 \mathrm{mg} / \mathrm{mL})$ for 60 minutes. Finally, the membranes were incubated in ECL Plus reagent for 5 to $15 \mathrm{mi}-$ nutes, and signals were visualized by exposure to Hyper Performance Chemiluminescence film. The band intensities were quantified with the use of ImageJ software version 1.48u $(\mathrm{NIH}$, Bethesda, MD) and were normalized to the

Table 3 Levels of Cholesterol in the Media of Primary Cultured Neurons Treated with Lovastatin for 24 Hours $(n=5)$

\begin{tabular}{lllll}
\hline & \multicolumn{2}{l}{ Lovastatin, $\mu \mathrm{mol} / \mathrm{L}$} & & \\
\cline { 2 - 5 } Variable & 0 (control) & 0.01 & 0.1 & 1 \\
\hline Cholesterol, $\mathrm{mmol} / \mathrm{L}$ & $0.590 \pm 0.054$ & $0.600 \pm 0.026$ & $0.624 \pm 0.028$ & $0.614 \pm 0.068$ \\
\hline
\end{tabular}

Values are presented as means \pm SD. 
Table 4 SOD Activity and MDA Content of SH-SY5Y/APP SWE $_{\text {and }}$ SH-SY5Y WT Cells with and without Exposure to Lovastatin $(n=5)$

\begin{tabular}{|c|c|c|c|}
\hline Cells & Lovastatin & $\begin{array}{l}\text { SOD } \\
\text { activity, } \\
\text { inhibition \% }\end{array}$ & $\begin{array}{l}\text { MDA, pmol } \\
\text { /mg protein }\end{array}$ \\
\hline SH-SY5Y WT & - & $95.6 \pm 0.63$ & $30.4 \pm 0.31$ \\
\hline SH-SY5Y WT & + & $93.3 \pm 0.24$ & $30.7 \pm 0.12$ \\
\hline SH-SY5Y/APP ${ }_{S W E}$ & - & $82.4 \pm 0.86^{*}$ & $39.6 \pm 0.22^{*}$ \\
\hline SH-SY5Y/APP & + & $91.2 \pm 1.04^{\dagger}$ & $30.8 \pm 0.52^{\dagger}$ \\
\hline
\end{tabular}

Values are presented as means \pm SD.

${ }^{*} P<0.05$ versus the SH-SY5Y WT cells.

${ }^{\dagger} P<0.05$ versus SH-SY5Y/APP ${ }_{\text {SWE }}$ cells.

APP, amyloid precursor protein; MDA, malondialdehyde; SOD, superoxide dismutase; WT, wild-type.

corresponding signal for $\beta$-actin (as an internal control for protein loading).

After extraction of cellular RNA with TRIzol Reagent, $1 \mu \mathrm{g}$ was subjected to reverse transcription with primers specific for $\alpha 7, \alpha 4, \alpha 3$, or $\beta 2$ nAChR mRNA (Table 2). Quantitative realtime PCR was performed in the ABI PRISM 7300 Sequence Detection System (Applied Biosystems, Foster City, CA) in accordance with the manufacturer's protocol and analyzed with GeneAmp7300 SDS software version 1.4u (Applied Biosystems). ${ }^{34}$ The levels of $\alpha 7, \alpha 4, \alpha 3$, and $\beta 2 \mathrm{nAChR}$ transcripts were estimated with $2^{-\Delta \Delta C \mathrm{~T}}(\mathrm{RQ}$ value) and the formula $\Delta \Delta C_{\mathrm{T}}=\Delta C_{\text {TTarget }}-\Delta C_{\text {Tcontrol }}=\left(C_{\text {TTarget }}\right.$ $\left.C_{\text {TActin }}\right)-\left(C_{\text {Tcontrol }}-C_{\text {TActin }}\right)$. The error was estimated as $\Delta \Delta C_{\mathrm{T}}$ plus and minus the $\mathrm{SD}$.

Analysis of the Phosphorylation of ERK1/2, JNK, and p38, and Levels of $\alpha$ APP, $\beta A P P$, APP, ADAM10, BACE1, and BACE2 by Western Blot Analysis

For quantitation of $\alpha$ APP and $\beta$ APP, the medium from cell cultures was first centrifuged at $15,000 \times g$ for 15 minutes to remove nonadherent cells and debris. After dilution with NuPAGE LDS sample buffer, aliquots $(40 \mu \mathrm{L} /$ well) were separated on $4 \%$ to $12 \%$ Bis-Tris Gels and blotted onto PVDF membranes. These membranes were subsequently incubated with mouse monoclonal 6E10 antibody (dilution $1: 1000$ ) against $\alpha \mathrm{APP}$ or mouse polyclonal $22 \mathrm{C} 11$ antibody (dilution 1:1000) against $\beta$ APP for 120 minutes at room temperature and then with anti-mouse IgG antibody
A



D

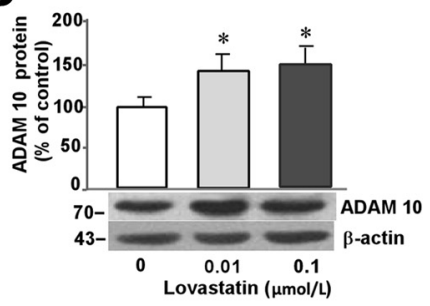

G

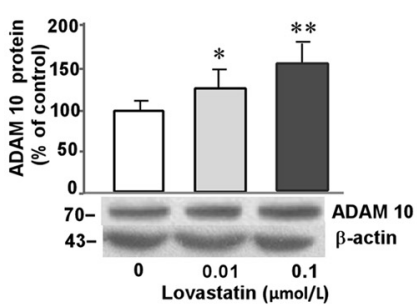

B



E

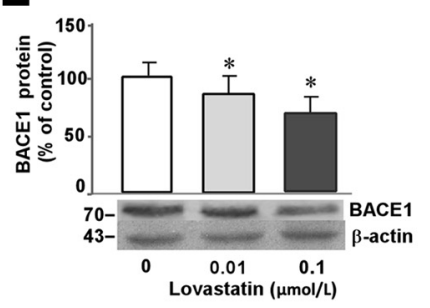

H

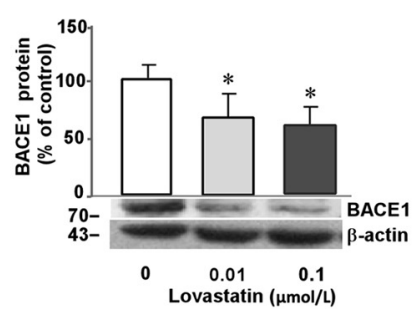

C
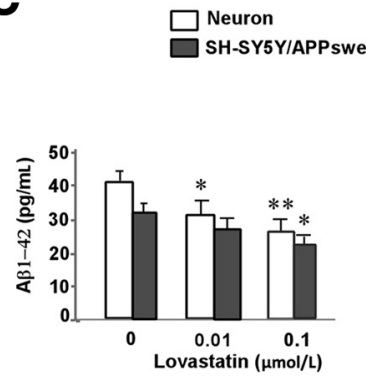

$\mathbf{F}$

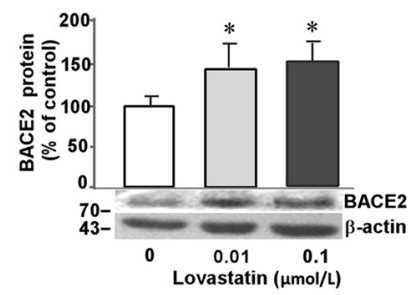

I

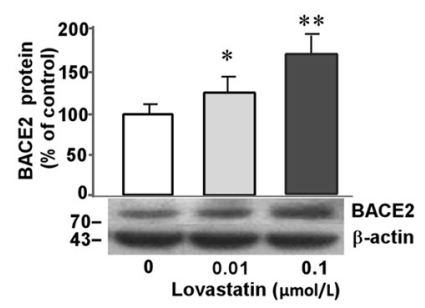

Figure 3 The levels of $\alpha$ amyloid precursor protein (APP), $\beta A P P, A P P, \beta$-amyloid peptide $(A \beta) 1$ to A $\beta 42$, disintegrin metalloproteinase domain-containing protein (ADAM)10, $\beta$-site amyloid precursor protein-cleaving enzyme (BACE)1, and BACE2 protein after treatment of cells with 0.01 or $0.1 \mu$ mol/L lovastatin for 24 hours. A, C-F: $\alpha A P P, \beta A P P$, and APP (A); A $\beta 1$ to A $\beta 42$ (C); ADAM10 (D); BACE1 (E); and BACE2 (F) in primary neurons. $\alpha A P P, \beta A P P$, and APP (B); A $\beta 1$ to $\mathrm{AB42}(\mathbf{C})$; ADAM10 (G); BACE1 (H); and BACE2 (I) in SH-SY5Y/APP ${ }_{\text {swe }}$ cells. Data are expressed as means \pm SD. $n=5 .{ }^{*} P<0.05, * * P<0.01$ versus untreated cells $(0)$ as determined by analysis of variance with the $U$-test. Representative immunoblots are depicted below the bar graphs. 

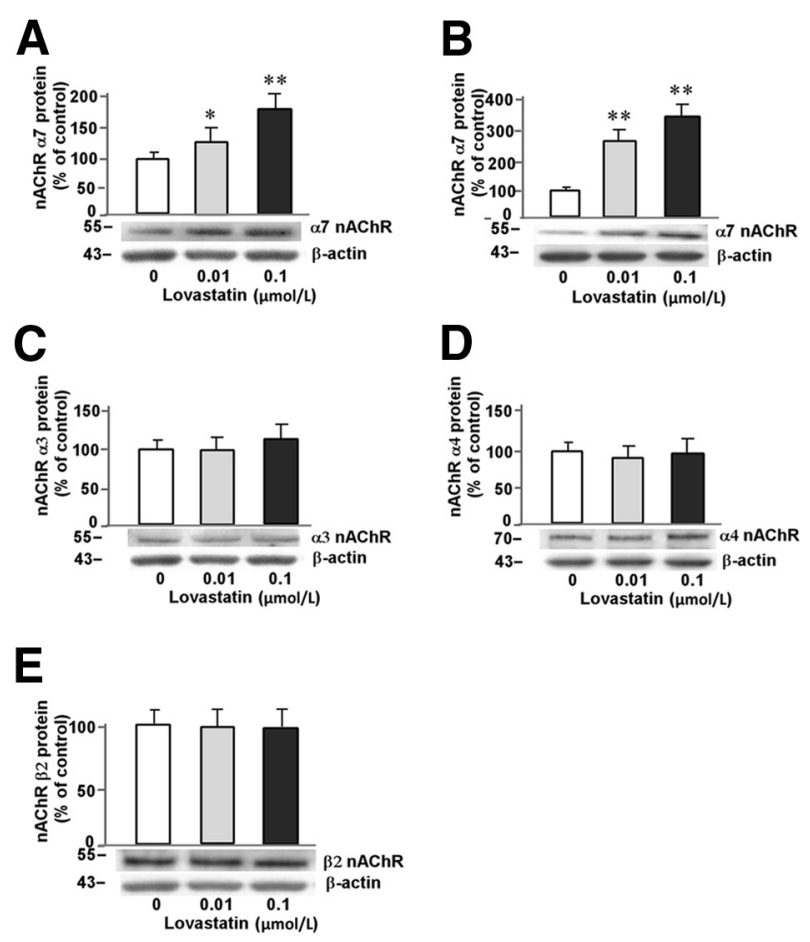

Figure 4 The levels of $\alpha 7, \alpha 4, \alpha 3$, or $\beta 2$ nicotinic acetylcholine receptor (nAChR) protein after treatment of cells with 0.01 or $0.1 \mu \mathrm{mol} / \mathrm{L}$ lovastatin for 24 hours. A-E: The levels of $\alpha 7$ nAChR in primary neurons (A) and in SH-SY5Y/APP swe $_{\text {e }}$ cells (B), and the levels of $\alpha 3, \alpha 4$, or $\beta 2$ protein in the primary neurons $(\mathbf{C}-\mathbf{E})$. Data are expressed as means \pm SD. $n=5$. ${ }^{*} P<0.05,{ }^{* *} P<0.01$ compared with untreated cells $(0)$ as determined by analysis of variance with the $U$-test. Representative immunoblots are depicted below the bar graphs.

(dilution 1:8000) for 60 minutes at room temperature. Visualization and analysis of the bands were performed as described above.

For quantitation of the extent of ERK1/2, JNK, and p38 phosphorylation, total protein was extracted from the cells with lysis buffer plus Protease/Phosphatase Inhibitor Cocktail and quantified with the DC Protein Assay kit. Aliquots (30 $\mu \mathrm{g} / \mathrm{well})$ were separated by $10 \%$ SDS-PAGE and then blotted onto PVDF membranes for measurement of phosphorylated and total proteins on separate membranes in the same test. These membranes were then incubated with rabbit monoclonal antibodies against either phospho-p44/42

Table 5 Levels of $\alpha 7, \alpha 4, \alpha 3$, and $\beta 2$ nAChR mRNA [Expressed as $\left.\mathrm{RQ}\left(2^{-} \triangle \triangle_{\mathrm{CT}}\right)\right]$ in Primary Cultured Neurons Treated with Lovastatin for 24 Hours $(n=5)$

\begin{tabular}{llrr}
\hline & & \multicolumn{3}{l}{ Lovastatin, $\mu \mathrm{mol} / \mathrm{L}$} \\
\cline { 3 - 4 } nAChR subunit & 0 (control) & \multicolumn{1}{l}{0.01} & \multicolumn{1}{l}{0.1} \\
\hline$\alpha 7$ & $1(0.9-1.1)$ & $1.76(1.2-2.3)^{*}$ & $2.72(2.1-3.3)^{\dagger}$ \\
$\alpha 4$ & $1(0.9-1.1)$ & $0.996(0.5-1.5)$ & $1.03(0.1-1.9)$ \\
$\alpha 3$ & $1(0.9-1.1)$ & $1.08(0.8-1.3)$ & $0.982(0.8-1.2)$ \\
$\beta 2$ & $1(0.9-1.1)$ & $0.920(0.5-1.3)$ & $0.973(0.1-1.8)$ \\
\hline
\end{tabular}

Values are presented as means (ranges).

${ }^{*} P<0.05$ versus the control value.

${ }^{\dagger} P<0.01$ versus the control value.

$\mathrm{nAChR}$, nicotinic acetylcholine receptor.
MAPK (dilution 1:2000), phospho-JNK MAPK (dilution 1:1000), phospho-p38 MAPK (dilution 1:1000), p44/42 MAPK (dilution 1:1000), JNK MAPK (dilution 1:1000), or p38 MAPK (dilution 1:1000) for 120 minutes at room temperature and, after washing, with anti-rabbit $\operatorname{IgG}$ (dilution 1:5000) for 60 minutes. The signals were again visualized and analyzed as already described.

In the case of APP, disintegrin metalloproteinase domaincontaining protein 10 (ADAM10), $\beta$-site amyloid precursor protein-cleaving enzyme (BACE)1, and BACE2, total protein was also extracted from the cells with lysis buffer plus Protease Inhibitor, and quantified with the DC Protein Assay kit. Aliquots (30 $\mu \mathrm{g} /$ well) were separated by $10 \%$ SDS-PAGE and then blotted onto PVDF membranes. These membranes were then incubated with rabbit monoclonal anti-ADAM10 (dilution 1:1000) or anti-BACE2 (dilution 1:1000) antibodies or mouse monoclonal 6E10 (dilution 1:1000) or anti-BACE (dilution 1:1000) antibodies for 120 minutes at room temperature and, after washing, with anti-rabbit IgG (dilution 1:5000) or anti-mouse IgG (dilution 1:8000) for 60 minutes.

\section{Analysis of $A \beta 1$ to $A \beta 42$ by ELISA}

For quantitation of $A \beta 1$ to $A \beta 42$, the medium from cell cultures was first centrifuged at $15,000 \times g$ for 15 minutes to remove nonadherent cells and debris and thereafter concentrated 10-fold with an ultrafiltration tube (Millipore). $\mathrm{A} \beta 1$ to $\mathrm{A} \beta 42$ was quantitated with the $\beta$-Amyloid (1-42) ELISA Kit or mouse A $\beta 42$ ELISA kit in accordance with the supplier's protocol.

\section{Statistical Analysis}

The values for the different groups are expressed as means $\pm \mathrm{SD}$ and were compared by analysis of variance with the $U$-test with the use of SPSS software version 17.0 (SPSS Inc., Chicago, IL).

\section{Results}

\section{Purity of the Primary Cultures of Neurons}

Immunostaining of the cells prepared from the hippocampal region of the brains of newborn rats with antibodies directed toward the neuronal marker NeuN and against glial fibrillary acidic protein, a marker for astrocytes, revealed that approximately $90 \%$ of these cells were neurons (Figure 1, A-D). The levels of APP protein and

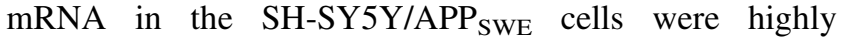
elevated (Figure 1, E and F).

Viability of and Levels of Cholesterol and $A \beta 1$ to $A \beta 42$ in Cultured Cells Exposed to Lovastatin

In accordance with the findings on astrocytes, ${ }^{18}$ exposure to 1 $\mu \mathrm{mol} / \mathrm{L}$ lovastatin reduced the viability of primary 
A

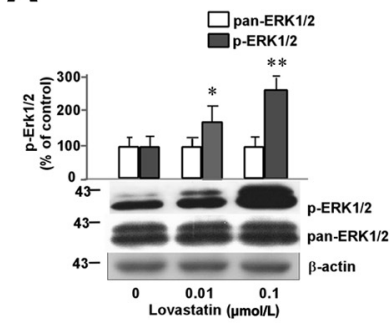

E

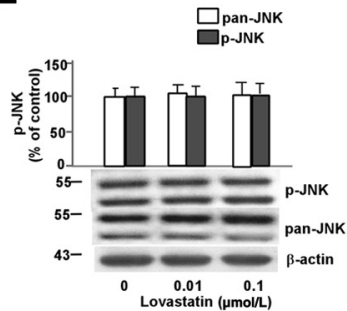

B

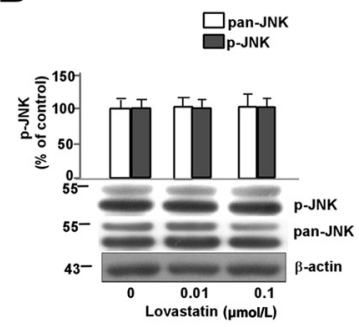

C

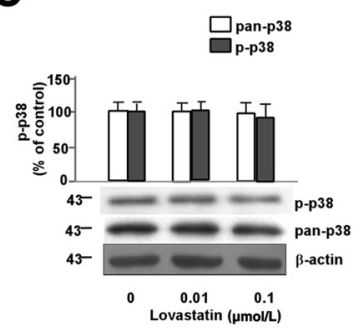

D

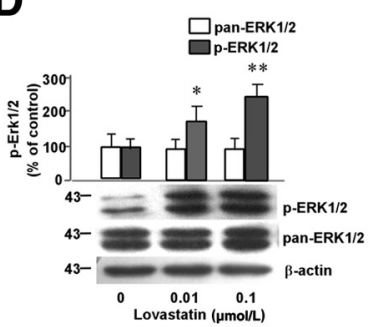

F

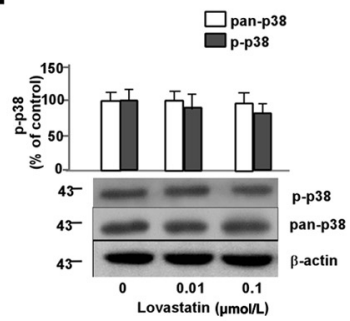

G

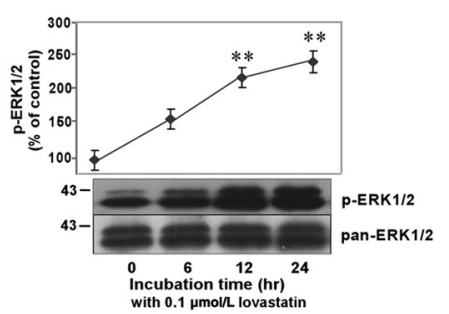

H

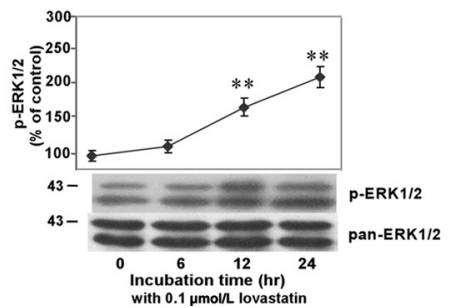

Figure 5 The levels of phospho (p)-extracellular signal-regulated kinase (ERK)1/2, $-c$-Jun $\mathrm{NH}_{2}$-terminal kinase (JNK), and - $\mathrm{p} 38$ after treatment of cells with lovastatin. A, D, G, and $\mathbf{H}$ : Dose- and time-dependent activation of ERK1/2 on incubation of primary neurons (A and $\mathbf{G})$ and SH-SY5Y/APP swe $_{\text {cells }}(\mathbf{D}$ and H) with lovastatin for 24 hours. B, C, E, and F: Activation of JNK and p38 in primary neurons (B and C) and SH-SY5Y/APP swe cells (E and F) after treatment with 0.01 or $0.1 \mu \mathrm{mol} / \mathrm{L}$ lovastatin for 24 hours. The signals for phospho-ERK1/2, -JNK, or -p38 were normalized to the corresponding $\beta$-actin signal (as an internal control for protein loading). Then, the value for the control groups were set to $100 \%$, and those for the other groups were expressed as a percentage of the control. No change in the total amount of ERK1/2, JNK, or p38 was found. Data are expressed as means \pm SD. $n=5 .{ }^{*} P<0.05$, ${ }^{* *} P<0.01$ versus untreated cells $(0)$ as determined by analysis of variance with the $U$-test. Representative immunoblots are depicted beneath the graphs.

hippocampal neurons by $40 \%$ and of SH-SY5Y/APP ${ }_{\mathrm{SWE}}$ cells by $50 \%$ (Figure $2 \mathrm{~A}$ ), at the same time decreasing the level of cholesterol in the neurons (Figure 2B) but not in the medium (Table 3). Because neither 0.01 nor $0.1 \mu \mathrm{mol} / \mathrm{L}$ lovastatin was cytotoxic or affected the level of cholesterol, these concentrations were chosen for further treatment. Interestingly, the viability of SH-SY5Y/APP ${ }_{S W E}$ cells was significantly lower than that of the corresponding wild-type (WT) cells, the viability of which was actually enhanced by $0.1 \mu \mathrm{mol} / \mathrm{L}$ lovastatin (Figure 2, C and D). The amount of $\mathrm{A} \beta 1$ to $\mathrm{A} \beta 42$ generated by SH-SY5Y/APP ${ }_{\mathrm{SWE}}$ cells was, as expected, higher than that by SH-SY5Y WT cells and, furthermore, was attenuated by $0.1 \mu \mathrm{mol} / \mathrm{L}$ lovastatin (Figure 2E).

\section{SOD Activity and MDA Levels in Cultured Cells} Expressing Elevated Levels of APP on Exposure to Lovastatin

The clearly lower SOD activity and elevated MDA content

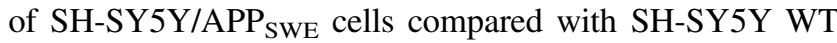
cells after starvation (in serum-free medium) for 48 hours were both reversed by exposure to $0.1 \mu \mathrm{mol} / \mathrm{L}$ lovastatin for 24 hours (Table 4).

Effects of Lovastatin on the Expression of $\alpha A P P, \beta A P P$, $A \beta 1$ to $A \beta 42, A D A M 10, B A C E 1$, and BACE2

After exposure to 0.01 or $0.1 \mu \mathrm{mol} / \mathrm{L}$ lovastatin for 24 hours, an increased level of $\alpha \mathrm{APP}$ and decreased levels of $\beta A P P$ and $A \beta 1$ to $A \beta 42$ were observed in both primary neurons (Figure 3, A and C) and SH-SY5Y/APP ${ }_{\mathrm{SwE}}$ cells (Figure 3, B and C), with no change in the level of fulllength APP in either case. At the same time, the level of BACE1 was reduced and expression of ADAM10 and BACE2 elevated in both primary neurons (Figure 3, D-F) and SH-SY5Y/APP ${ }_{\text {SwE }}$ cells (Figure 3, G-I).

Levels of $\alpha 7, \alpha 4, \alpha 3$, and $\beta 2 \mathrm{nAChR}$ Protein and mRNA Are Altered by Lovastatin

On exposure to 0.01 or $0.1 \mu \mathrm{mol} / \mathrm{L}$ lovastatin for 24 hours, the level of $\alpha 7 \mathrm{nAChR}$ subunit protein was significantly elevated in both primary neurons (Figure $4 \mathrm{~A}$ ) and $\mathrm{SH}$ SY5Y/APP $_{\text {SWE }}$ cells (Figure 4B), with no change in the levels of $\alpha 3, \alpha 4$, and $\beta 2$ protein in the primary neurons (Figure 4, C-E). A similar pattern with respect to mRNA levels was observed for these primary neurons (Table 5). As reported previously, ${ }^{18}$ the levels of $\alpha 4, \alpha 3$, and $\beta 2 \mathrm{nAChR}$ protein and mRNA in the SH-SY5Y/APP SWE $_{\text {cells did not }}$ change (not shown).

\section{Effects of Lovastatin on ERK1/2, JNK, and p38}

In both primary neurons (Figure 5A) and SH-SY5Y/ $\mathrm{APP}_{\mathrm{SWE}}$ cells (Figure 5D), activating phosphorylation of ERK1/2 was enhanced $170 \%$ and $220 \%$ on exposure to 0.01 or $0.1 \mu \mathrm{mol} / \mathrm{L}$ lovastatin, respectively, in a time-dependent fashion (Figure 5, G and $\mathrm{H}$ ). No change in the level of phospho-JNK or phospho-p38 was observed in either the 


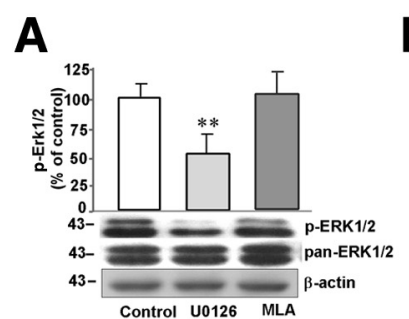

B

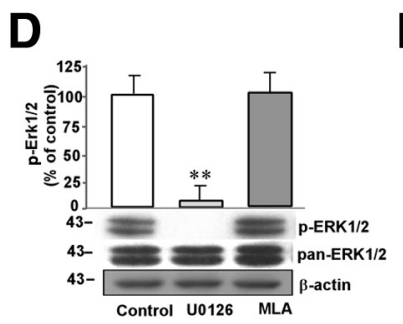

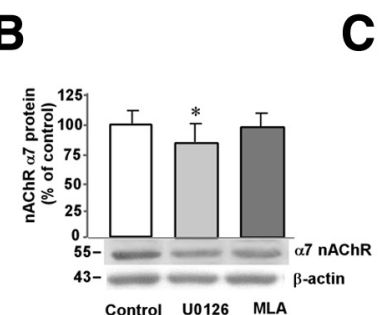

C
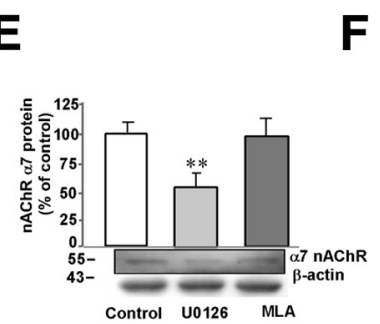

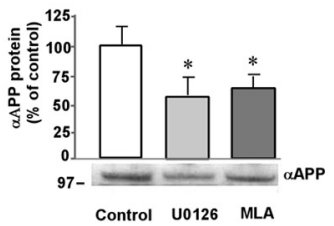

$\mathbf{F}$

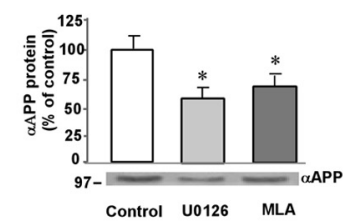

Figure 6 A-F: The levels of phospho ( $p$ ) -extracellular signal-regulated kinase (ERK) $1 / 2$ and $\alpha 7$ nicotinic acetylcholine receptor (nAChR) and secretion of $\alpha$ amyloid precursor protein (APP) after treatment of primary neurons $(\mathbf{A}-\mathbf{C})$ and $\mathrm{SH}-$ SY5Y/APP swe cells (D-F) with $10 \mu \mathrm{mol} / \mathrm{L}$ U0126 or methyllycaconitine (MLA) for 24 hours. Data are expressed as means \pm SD. $n=5$. ${ }^{*} P<0.05$, ${ }^{* *} P<0.01$ versus untreated cells (control) as determined by analysis of variance with the $U$-test. Representative immunoblots are depicted below the bar graphs. primary neurons (Figure 5, B and C) or SH-SY5Y/APP ${ }_{\mathrm{SWE}}$ cells (Figure 5, E and F) nor were the total amounts of ERK1/2, JNK, or p38 altered (Figure 5).

\section{Effects of U0126 and MLA on the Expression of $\alpha 7$ nAChR, Activation of ERK1/2, and Release of $\alpha$ APP from Cultured Cells}

When primary neurons were treated with $10 \mu \mathrm{mol} / \mathrm{L}$ U0126 for 24 hours, phosphorylation of ERK1/2 was inhibited (Figure 6A), expression of $\alpha 7 \mathrm{nAChR}$ reduced (Figure 6B), and release of $\alpha$ APP lowered (Figure 6C), with the same changes being observed in the case of SH-SY5Y/APP ${ }_{\mathrm{SWE}}$ cells (Figure 6, D-F). However, on exposure to $10 \mu \mathrm{mol} / \mathrm{L}$ MLA for 24 hours, only lowered release of $\alpha \mathrm{APP}$ was observed in primary neurons (Figure 6C) and SH-SY5Y/ $\mathrm{APP}_{\text {SWE }}$ cells (Figure 6F), with no change in the level of phospho-ERK1/2 (Figure 6, A and D) or $\alpha 7 \mathrm{nAChR}$ (Figure 6, B and E).

Furthermore, exposure to $0.1 \mu \mathrm{mol} / \mathrm{L}$ lovastatin alone stimulated expression of $\alpha 7 \mathrm{nAChR}$ and activation of ERK1/ 2 , as well as secretion of $\alpha \mathrm{APP}$ in both primary neurons
A

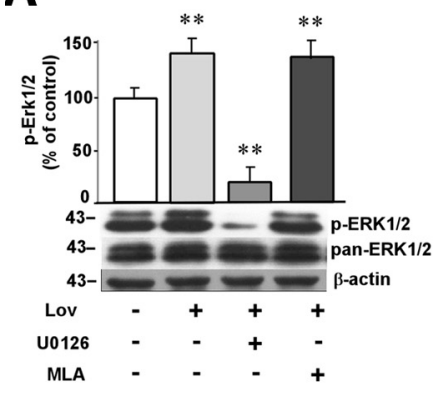

D

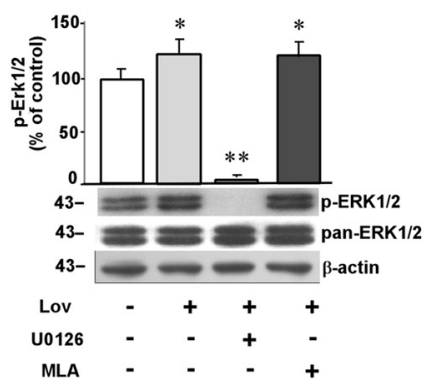

B

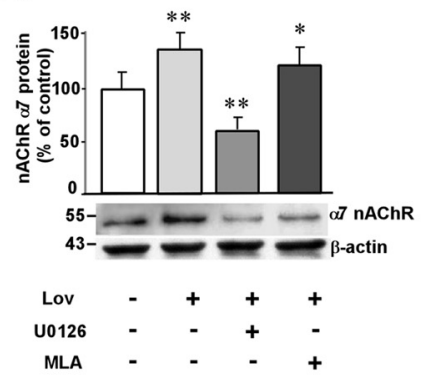

E

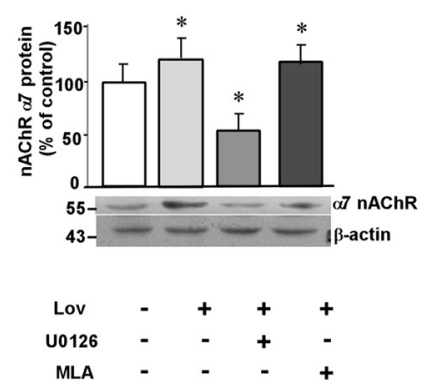

C

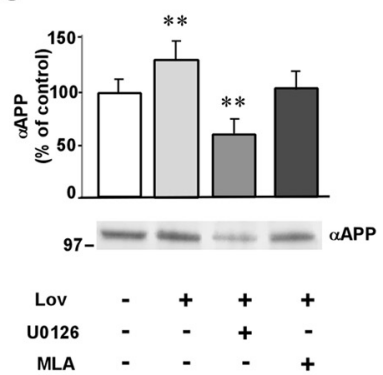

$\mathbf{F}$

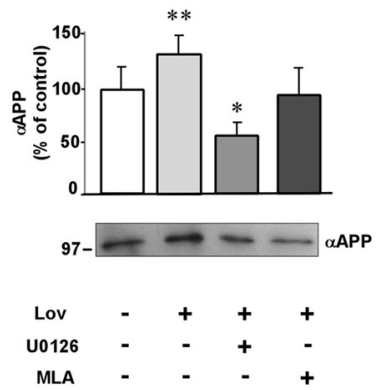

Figure $7 \quad$ A-F: The levels of phospho ( $p$ )-extracellular signal-regulated kinase (ERK)1/2 and $\alpha 7$ nicotinic acetylcholine receptor (nAChR) and secretion of $\alpha$ amyloid precursor protein (APP) by primary neurons $(\mathbf{A}-\mathbf{C})$ or SH-SY5Y/APP swe cells $(\mathbf{D}-\mathbf{F})$ on exposure to lovastatin alone (Lov; $0.1 \mu \mathrm{mol} / \mathrm{L})$ for 24 hours or after preincubation with $10 \mu \mathrm{mol} / \mathrm{L}$ U0126 or methyllycaconitine (MLA) for 2 hours. Data are expressed as means \pm SD. $n=5 .{ }^{*} P<0.05, * * P<0.01$ versus untreated cells (control) as determined by analysis of variance with the $U$-test. Representative immunoblots are depicted below the bar graphs. 

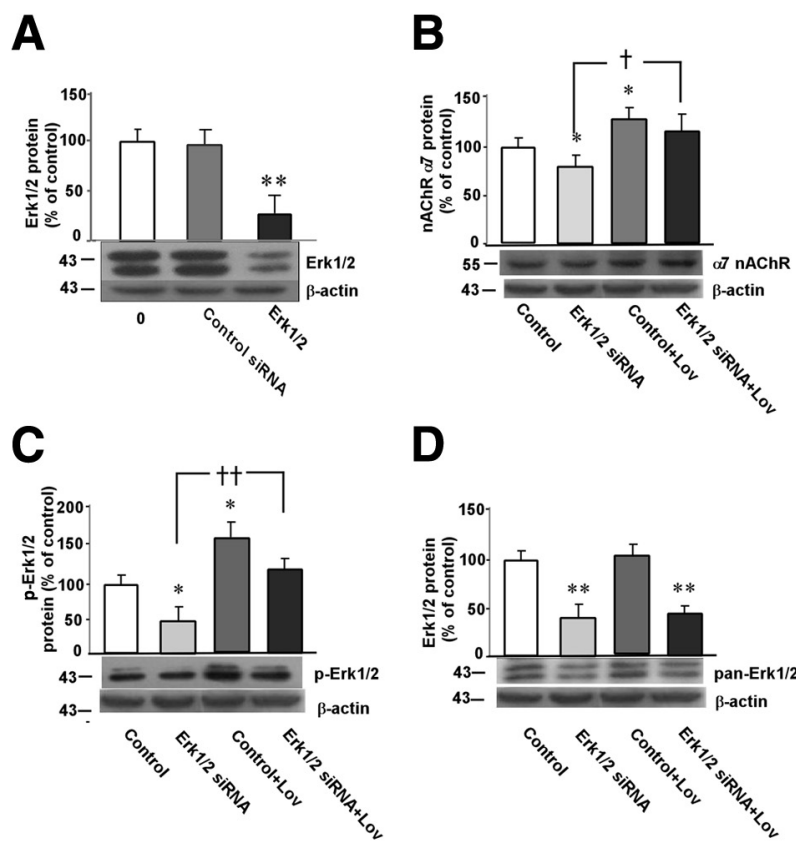

D
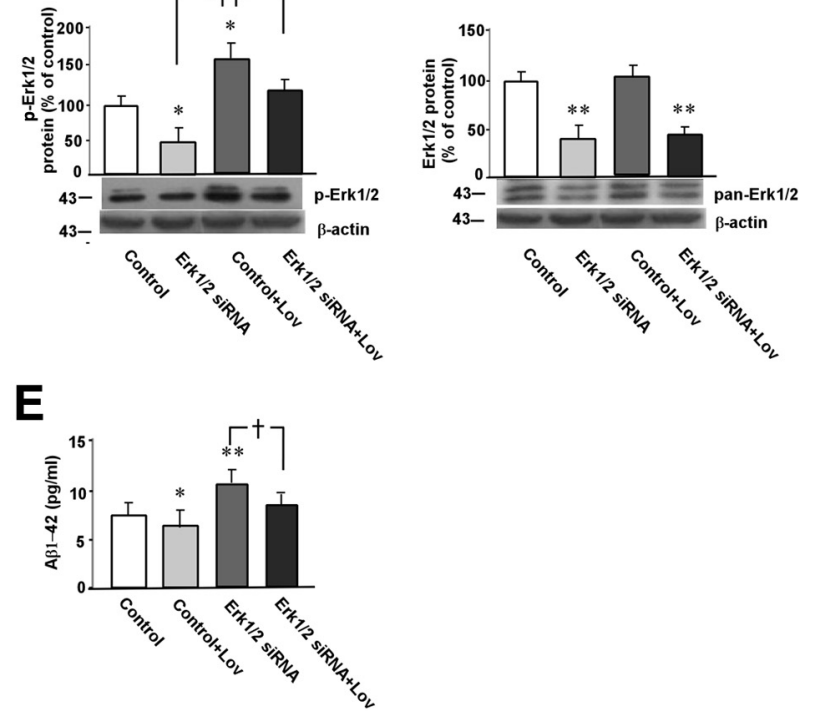

Figure 8 The levels of phospho (p)-extracellular signal-regulated kinase (ERK)1/2 and ERK1/2, $\alpha 7$ nicotinic acetylcholine receptor ( $\mathrm{nAChR}$ ) in and secretion of $\beta$-amyloid peptide (A $\beta) 1$ to $A \beta 42$ by SH-SY5Y cells after treatment with ERK1/2 siRNA or/and lovastatin. A: ERK1/2 after treatment with $100 \mathrm{nmol} / \mathrm{L}$ ERK1/2 siRNA for 48 hours. B-E: The levels of $\alpha 7 \mathrm{nAChR}$ (B), phospho-ERK1/2 (C), ERK1/2 (D), and A 31 to $A \beta 42(E)$ on exposure to ERK1/2 siRNA or control siRNA for 48 hours alone or in combination with lovastatin (Lov; $0.1 \mu \mathrm{mol} / \mathrm{L}$ ) for 24 hours. Data are expressed as means \pm SD. $n=5 .{ }^{*} P<0.05,{ }^{*} P<0.01$ versus untreated cells $(0$ or control) ${ }^{\dagger} P<0.05,{ }^{\dagger \dagger} P<0.01$ versus SH-SY5Y cells transfected with ERK1/ 2 siRNA, as determined by analysis of variance with the $U$-test. Representative immunoblots are also depicted.

(Figure 7, A-C) and SH-SY5Y/APP ${ }_{\mathrm{SWE}}$ cells (Figure 7, D-F). In the presence of both lovastatin and U0126, all of these alterations were attenuated dramatically (Figure 7). In addition, in combination with MLA, lovastatin still stimulated activation of ERK1/2 (Figure 7, A and D) and expression of $\alpha 7 \mathrm{nAChR}$ (Figure 7, B and E), but it no longer elevated secretion of $\alpha$ APP (Figure 7, C and F).

Effect of ERK1/2 siRNA on the Expression of $\alpha 7$ nAChR, Phospho-ERK1/2, and ERK1/2, and on the Release of $A \beta 1$ to $A \beta 42$ from SH-SY5Y Cells

When SH-SY5Y cells were transfected with ERK1/2 siRNA for 72 hours, the levels of ERK1/2 (Figure 8, A and D), $\alpha 7$ nAChR (Figure 8B), and phospho-ERK1/2 (Figure 8C) were all lowered and the release of $A \beta 1$ to $A \beta 42$
(Figure 8E) enhanced in comparison with cells transfected with the control siRNA. Furthermore, on exposure to 0.1 $\mu \mathrm{mol} / \mathrm{L}$ lovastatin, with the exception of the increased expression of ERK1/2 (Figure 8D), all of these changes were reversed (Figure 8, A-C and E).

\section{Discussion}

The considerable effort already devoted to the development of therapeutic agents has yet to result in either effective prevention or a cure for Alzheimer disease. ${ }^{36,37}$ Current pharmacotherapy is still limited to the use of cholinesterase inhibitors, although inhibitors of $\beta$-secretase, as well as immunotherapy, are also being explored. ${ }^{36}$

Interestingly, statins, inhibitors of 3-hydroxy-3methylglutaryl-coenzyme A reductase, used worldwide to lower blood levels of cholesterol in connection with treatment of cardiovascular disease, ${ }^{38}$ exert other pleiotropic cholesterol-independent effects, including on inflammation, atherosclerosis, oxidative stress, cellular proliferation, and differentiation ${ }^{11-14,38,39}$; therefore, they have been proposed for treatment of other diseases as well. Recently, the use of statins has also been associated with a lowered risk of death and of developing $\mathrm{AD} .^{40} \mathrm{~A}$ clinical study on 719 patients with mild-to-moderate $\mathrm{AD}$ revealed that early statin use slowed progression of their disease. ${ }^{41}$

Here, we demonstrated that SH-SY5Y/APP ${ }_{\text {SwE }}$ cells exhibit reduced cell viability, lower SOD activity, more lipid peroxidation, and enhanced secretion of $A \beta 1$ to $A \beta 42$ in comparison with the corresponding WT cells. Interestingly, pretreatment with low concentrations of lovastatin attenuated all of these neurotoxic differences without altering the cellular level of cholesterol. These observations provide further evidence for the cholesterol-independent protective effect of lovastatin, in agreement with our previous findings. ${ }^{17-19}$

Numerous reports have found that statins can lower cellular production of $A \beta$ by modulating the processing of APP. For example, treatment of rat primary cortical neurons or neurons overexpressing APP with pitavastatin and atorvastatin reduces this production by selectively modulating the maturation and phosphorylation of APP through a mechanism independent of any reduction in cholesterol levels. ${ }^{14}$ Moreover, simvastatin significantly decreases the level of insoluble $A \beta$ peptide and $A \beta$ plaque load in the brains of bi-transgenic $\mathrm{APP}_{\mathrm{SWE}}$ and Ind/transforming growth factor- $\beta 1$ mice. ${ }^{42,43}$ Previously, we observed that lovastatin, atorvastatin, rosuvastatin, and simvastatin (ie, both lipophilic and hydrophilic statins) all elevate the level of $\alpha$ APP in cultured cells significantly. ${ }^{17,19,44}$ Together, these findings indicate that statins may reduce the risk of developing $\mathrm{AD}$, at least in part, by modulating $\mathrm{APP}$ metabolism.

In the present investigation, when primary cultured neurons or SH-SY5Y/APP ${ }_{\mathrm{SWE}}$ cells were exposed to 


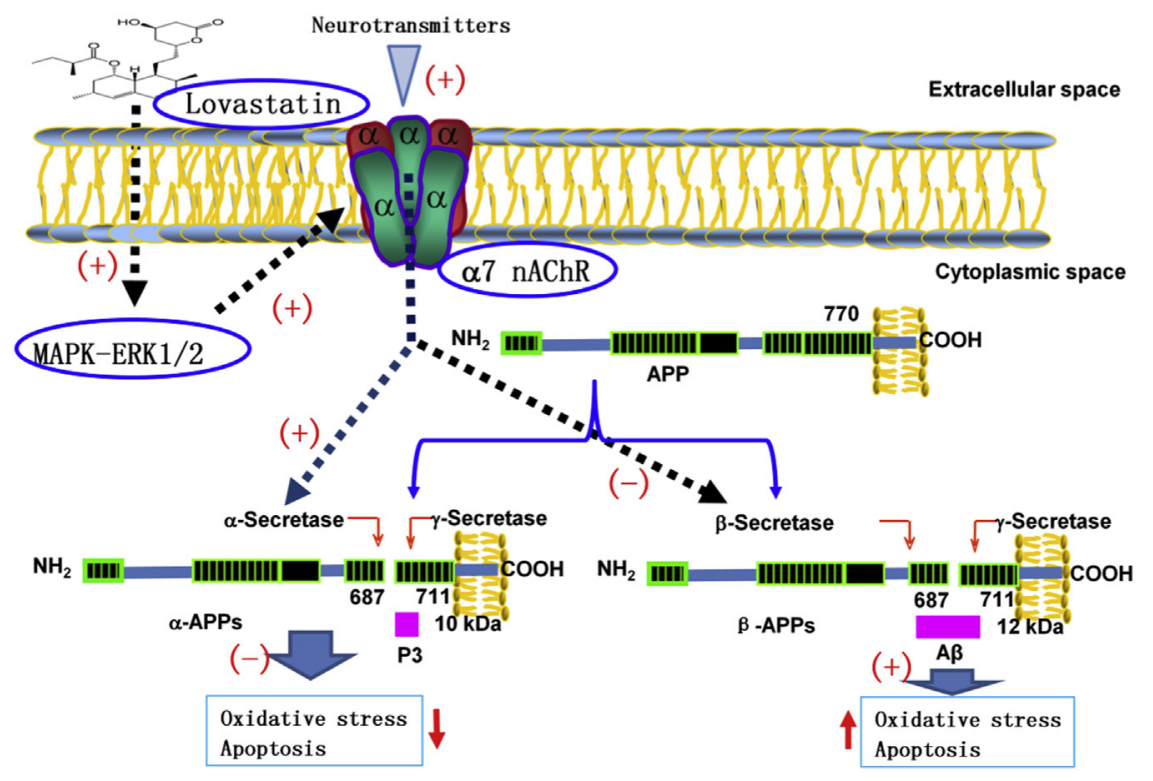

Figure 9 The mechanism proposed to underlie the neuroprotective effect of lovastatin toward Alzheimer disease (AD). After being activated by lovastatin through the mitogen-activated protein kinase (MAPK) and extracellular signal-regulated kinase (ERK) $1 / 2$ pathway, ERK1/2 elevates the expression of $\alpha 7$ nicotinic acetylcholine receptor (nAChR) and stimulates the nonamyloidogenic processing of amyloid precursor protein (APP). This involves increases in the secretion of $\alpha$ APP and expression of disintegrin metalloproteinase domain-containing protein (ADAM) 10 and $\beta$-site amyloid precursor protein-cleaving enzyme (BACE) 2 , as well as reduced secretion of $\beta$-amyloid peptide $(A \beta) 1$ to $A \beta 42$ and expression of BACE1. Finally, the amount of $A \beta$ produced is lowered, and neurotoxicity thus is attenuated. concentrations of lovastatin that altered neither the cellular nor medium level of cholesterol, the activities of $\alpha$-secretase and BACE2 were enhanced, whereas the activity of BACE1 was inhibited, changes that may result in elevated secretion of $\alpha \mathrm{APP}$ and attenuated release of $\mathrm{A} \beta 1$ to $\mathrm{A} \beta 42$. These findings constitute further evidence that cholesterolindependent stimulation of nonamyloidogenic processing by lovastatin may lower production of $A \beta$ and thereby decrease the risk of developing AD.

The nAChRs play an important role in the pathogenesis of $\mathrm{AD}^{21,22}$ and may also contribute to therapy for $\mathrm{AD}$. Cholinesterase inhibitors may impair neuronal $\alpha 7 \mathrm{nAChR}^{45}$ subunits, whereas statins can protect their function directly. Accordingly, concurrent administration of statins may improve the efficacy of cholinesterase inhibitor treatment. ${ }^{46}$ Our present findings with primary cultured neurons and SHSY5Y/APP $_{\text {SWE }}$ cells are in complete accordance with our previous observations on primary astrocytes, ${ }^{17-19}$ in which low concentrations of lovastatin increased the levels of $\alpha 7$ protein and mRNA without altering the expression of $\alpha 4$, $\alpha 3$, or $\beta 2$ nAChRs.

APP metabolism is modulated by neurotransmitters and by protein kinases and phosphatases. ${ }^{47}$ Activation of MAPK/ERK is required for secretory processing of APP and for synaptic plasticity and memory. ${ }^{47-49}$ Chronic administration of simvastatin to mice prevents inhibition of protein kinase $B$ and phosphorylation of ERK2 by A $\beta 25$ to A $\beta 35 .{ }^{16}$ In the present study lovastatin enhanced ERK1/2 phosphorylation in primary neurons and $\mathrm{SH}-\mathrm{SY} 5 \mathrm{Y} / \mathrm{APP} \mathrm{SWE}_{\mathrm{SW}}$ cells, but it did not influence the expression of ERK1/2 nor cause any apparent alteration in the expression and phosphorylation of the JNK and p38 components of the MAPK signal pathway.

To elucidate the mechanisms underlying the potential protective effect of statins, changes in the relationships between MAPK/ERK, nAChRs, and APP metabolism in response to treatment with lovastatin, U0126, MLA, and/or ERK1/2 siRNA were examined. U0126, an inhibitor of MEK1/2, prevented all three of the effects of lovastatin on cells, that is, phosphorylation of ERK1/2, up-regulation of $\alpha 7 \mathrm{nAChR}$, and enhanced secretion of $\alpha \mathrm{APP}$, whereas MLA, an antagonist of $\alpha 7 \mathrm{nAChR}$, attenuated only the secretion of $\alpha$ APP. In addition, cells transfected with ERK1/ 2 siRNA, and then exposed to lovastatin, exhibited phosphorylation of ERK1/2, up-regulation of $\alpha 7 \mathrm{nAChR}$, and decreased secretion of $A \beta 1$ to $A \beta 42$ with no change in the total level of ERK1/2, again indicating that the effects of lovastatin involve activation of ERK1/2.

From these findings, we propose that lovastatin first activates ERK, which then stimulates expression of $\alpha 7$ nAChR and finally enhances the nonamyloidogenic pathway, activating $\alpha$-secretase, and thereby promoting production of $\alpha \mathrm{APP}$ and reducing the secretion of $\mathrm{A} \beta$. Although these effects may protect against $\mathrm{AD}$ in a cholesterol-independent manner, many potentially related mechanisms remain elusive. The pathways that involve Rasdependent MAPK and phosphoinositide 3-kinase have been reported to be critical for the increased neuronal transcriptional of a gene encoding $\mathrm{nAChR}$ in response to nerve growth factor. ${ }^{50}$ In addition, activation of MAPK/ERK is required for the increases in the levels of mRNA encoding all five subunits of AChR caused by AChR-inducing activity and for synapse-specific expression of the AChR epsilon-transgene. ${ }^{51}$ All of these observations are consistent with our hypothesis.

The present investigation demonstrates that the cholesterolindependent attenuation of the neurotoxic effects of $A \beta$ by lovastatin may primarily involve activation of the phosphoMAPK/ERK pathway, subsequent stimulation of $\alpha 7 \mathrm{nAChR}$ expression, and, finally, enhancement of the 
nonamyloidogenic pathway of APP processing (Figure 9). Although these insights may help improve treatment of AD, the therapeutic efficacy of statins in this context requires further elucidation.

\section{References}

1. Hardy J, Selkoe DJ: The amyloid hypothesis of Alzheimer's disease: progress and problems on the road to therapeutics. Science 2002, 297: $353-356$

2. Haass C, Selkoe DJ: Cellular processing of beta-amyloid precursor protein and the genesis of amyloid beta-peptide. Cell 1993, 75: $1039-1042$

3. Furukawa K, Sopher BL, Rydel RE, Begley JG, Pham DG, Martin GM, Fox M, Mattson MP: Increased activity-regulating and neuroprotective efficacy of alpha-secretase-derived secreted amyloid precursor protein conferred by a C-terminal heparin-binding domain. J Neurochem 1996, 67:1882-1896

4. Berk C, Paul G, Sabbagh M: Investigational drugs in Alzheimer's disease: current progress. Expert Opin Investig Drugs 2014, 23:837-846

5. Richardson K, Schoen M, French B, Umscheid CA, Mitchell MD, Arnold SE, Heidenreich PA, Rader DJ, deGoma EM: Statins and cognitive function: a systematic review. Ann Intern Med 2013, 159: 688-697

6. Shitara Y, Sugiyama Y: Pharmacokinetic and pharmacodynamic alterations of 3-hydroxy-3-methylglutaryl coenzyme A (HMG-CoA) reductase inhibitors: drug-drug interactions and interindividual differences in transporter and metabolic enzyme functions. Pharmacol Ther 2006, 112:71-105

7. Tamboli IY, Barth E, Christian L, Siepmann M, Kumar S, Singh S, Tolksdorf K, Heneka MT, Lütjohann D, Wunderlich P, Walter J: Statins promote the degradation of extracellular amyloid \{beta\}peptide by microglia via stimulation of exosome-associated insulindegrading enzyme (IDE) secretion. J Biol Chem 2010, 285: 37405-37414

8. Fassbender K, Simons M, Bergmann C, Stroick M, Lutjohann D, Keller P, Runz H, Kuhl S, Bertsch T, von Bergmann K, Hennerici M, Beyreuther K, Hartmann T: Simvastatin strongly reduces levels of Alzheimer's disease beta -amyloid peptides Abeta 42 and Abeta 40 in vitro and in vivo. Proc Natl Acad Sci U S A 2001, 98:5856-5861

9. Kojro E, Füger P, Prinzen C, Kanarek AM, Rat D, Endres K, Fahrenholz F, Postina R: Statins and the squalene synthase inhibitor zaragozic acid stimulate the non-amyloidogenic pathway of amyloidbeta protein precursor processing by suppression of cholesterol synthesis. J Alzheimers Dis 2010, 20:1215-1231

10. Mendoza-Oliva A, Ferrera P, Fragoso-Medina J, Arias C: Lovastatin differentially affects neuronal cholesterol and amyloid-beta production in vivo and in vitro. CNS Neurosci Ther 2015, 21:631-641

11. Liao JK, Laufs U: Pleiotropic effects of statins. Annu Rev Pharmacol Toxicol 2005, 45:89-118

12. Wang CY, Liu PY, Liao JK: Pleiotropic effects of statin therapy: molecular mechanisms and clinical results. Trends Mol Med 2008, 14:37-44

13. Butterfield DA, Barone E, Mancuso C: Cholesterol-independent neuroprotective and neurotoxic activities of statins: perspectives for statin use in Alzheimer disease and other age-related neurodegenerative disorders. Pharmacol Res 2011, 64:180-186

14. Hosaka A, Araki W, Oda A, Tomidokoro Y, Tamaoka A: Statins reduce amyloid beta-peptide production by modulating amyloid precursor protein maturation and phosphorylation through a cholesterol-independent mechanism in cultured neurons. Neurochem Res 2013, 38:589-600

15. Pac-Soo C, Lloyd DG, Vizcaychipi MP, Ma D: Statins: the role in the treatment and prevention of Alzheimer's neurodegeneration. J Alzheimers Dis 2011, 27:1-10
16. McGuinness B, Passmore P: Can statins prevent or help treat Alzheimer's disease? J Alzheimers Dis 2010, 20:925-933

17. Xiu J, Nordberg A, Shan KR, Yu WF, Olsson JM, Nordman T, Mousavi M, Guan ZZ: Lovastatin stimulates up-regulation of alpha7 nicotinic receptors in cultured neurons without cholesterol dependency, a mechanism involving production of the alpha-form of secreted amyloid precursor protein. J Neurosci Res 2005, 82: $531-541$

18. Xiu J, Nordberg A, Qi XL, Guan ZZ: Influence of cholesterol and lovastatin on alpha-form of secreted amyloid precursor protein and expression of alpha7 nicotinic receptor by astrocytes. Neurochem Int 2006, 49:459-465

19. Roensch J, Crisby M, Nordberg A, Xiao Y, Zhang LJ, Guan ZZ: Effects of statins on alpha7 nicotinic receptor, cholinesterase and alpha-form of secreted amyloid precursor peptide in SH-SY5Y cells. Neurochem Int 2007, 50:800-806

20. Paterson D, Nordberg A: Neuronal nicotinic receptors in the human brain. Prog Neurobiol 2000, 61:75-111

21. Guan ZZ, Zhang X, Ravid R, Nordberg A: Decreased protein levels of nicotinic receptor subunits in the hippocampus and temporal cortex of patients with Alzheimer's disease. J Neurochem 2000, 74: 237-243

22. Nordberg A: Nicotinic receptor abnormalities of Alzheimer's disease: therapeutic implications. Biol Psychiatry 2001, 49:200-210

23. Arthur JS, Ley SC: Mitogen-activated protein kinases in innate immunity. Nat Rev Immunol 2013, 13:679-692

24. Peti W, Page R: Molecular basis of MAP kinase regulation. Protein Sci 2013, 22:1698-1710

25. Kim EK, Choi EJ: Pathological roles of MAPK signaling pathways in human diseases. Biochim Biophys Acta 2010, 1802:396-405

26. Dineley KT, Westerman M, Bui D, Bell K, Ashe KH, Sweatt JD: Beta-amyloid activates the mitogen-activated protein kinase cascade via hippocampal alpha7 nicotinic acetylcholine receptors: in vitro and in vivo mechanisms related to Alzheimer's disease. J Neurosci 2001, 21:4125-4133

27. Bell KA, O’Riordan KJ, Sweatt JD, Dineley KT: MAPK recruitment by beta-amyloid in organotypic hippocampal slice cultures depends on physical state and exposure time. J Neurochem 2004, 91:349-361

28. Giraldo E, Lloret A, Fuchsberger T, Vina J: Abeta and tau toxicities in Alzheimer's are linked via oxidative stress-induced p38 activation: protective role of vitamin E. Redox Biol 2014, 2:873-877

29. Zhang LL, Sui HJ, Liang B, Wang HM, Qu WH, Yu SX, Jin Y: Atorvastatin prevents amyloid- $\beta$ peptide oligomer-induced synaptotoxicity and memory dysfunction in rats through a p38 MAPKdependent pathway. Acta Pharmacol Sin 2014, 35:716-726

30. Zhi WH, Zeng YY, Lu ZH, Qu WJ, Chen WX, Chen L, Chen L: Simvastatin exerts antiamnesic effect in A $\beta 25-35$-injected mice. CNS Neurosci Ther 2014, 20:218-226

31. Kandiah N, Feldman HH: Therapeutic potential of statins in Alzheimer's disease. J Neurol Sci 2009, 283:230-234

32. Nunez J: Primary culture of hippocampal neurons from P0 newborn rats. J Vis Exp 2008, 19. pii: 895

33. Pacifici M, Peruzzi F: Isolation and culture of rat embryonic neural cells: a quick protocol. J Vis Exp 2012, 63:e3965

34. An Y, Qi XL, Pei JJ, Tang Z, Xiao Y, Guan ZZ: Amyloid precursor protein gene mutated at Swedish 670/671 sites in vitro induces changed expression of nicotinic acetylcholine receptors and neurotoxicity. Neurochem Int 2010, 57:647-654

35. Fukuda T, Takeda S, Xu R, Ochi H, Sunamura S, Sato T, Shibata S, Yoshida Y, Gu Z, Kimura A, Ma C, Xu C, Bando W, Fujita K, Shinomiya K, Hirai T, Asou Y, Enomoto M, Okano H, Okawa A, Itoh $\mathrm{H}$ : Sema3A regulates bone-mass accrual through sensory innervations. Nature 2013, 497:490-493

36. Geldenhuys WJ, Darvesh AS: Pharmacotherapy of Alzheimer's disease: current and future trends. Expert Rev Neurother 2015, 15:3-5

37. Kumar A, Nisha CM, Silakari C, Sharma I, Anusha K, Gupta N, Nair P, Tripathi T, Kumar A: Current and novel therapeutic molecules 
and targets in Alzheimer's disease. J Formos Med Assoc 2016, 115: $3-10$

38. Miida T, Hirayama S, Nakamura Y: Cholesterol-independent effects of statins and new therapeutic targets: ischemic stroke and dementia. J Atheroscler Thromb 2004, 11:253-264

39. Takemoto M, Liao JK: Pleiotropic effects of 3-hydroxy-3methylglutaryl coenzyme a reductase inhibitors. Arterioscler Thromb Vasc Biol 2001, 21:1712-1719

40. Williams PT: Lower risk of Alzheimer's disease mortality with exercise, statin, and fruit intake. J Alzheimers Dis 2015, 44:1121-1129

41. Lin FC, Chuang YS, Hsieh HM, Lee TC, Chiu KF, Liu CK, Wu MT: Early statin use and the progression of Alzheimer disease: a total populationbased case-control study. Medicine (Baltimore) 2015, 94:e2143

42. Papadopoulos P, Tong XK, Hamel E: Selective benefits of simvastatin in bitransgenic APPSwe, Ind/TGF-betal mice. Neurobiol Aging 2014, 35:203-212

43. Eckert GP, Reik C, Müller WE: Simvastatin alters membrane cholesterol distribution and beta-amyloid levels in brains of female APP751SL mice. Pharmazie 2013, 68:590-594

44. Simons M, Keller P, De Strooper B, Beyreuther K, Dotti CG, Simons K: Cholesterol depletion inhibits the generation of beta-amyloid in hippocampal neurons. Proc Natl Acad Sci U S A 1998, 95:6460-6464

45. Mozayan M, Chen MF, Si M, Chen PY, Premkumar LS, Lee TJ: Cholinesterase inhibitor blockade and its prevention by statins of sympathetic alpha7-nAChR-mediated cerebral nitrergic neurogenic vasodilation. J Cereb Blood Flow Metab 2006, 26:1562-1576

46. Mozayan M, Lee TJ: Statins prevent cholinesterase inhibitor blockade of sympathetic alpha7-nAChR-mediated currents in rat superior cervical ganglion neurons. Am J Physiol Heart Circ Physiol 2007, 293: H1737-H1744

47. Desdouits-Magnen J, Desdouits F, Takeda S, Syu LJ, Saltiel AR, Buxbaum JD, Czernik AJ, Nairn AC, Greengard P: Regulation of secretion of Alzheimer amyloid precursor protein by the mitogenactivated protein kinase cascade. J Neurochem 1998, 70:524-530

48. Mills J, Laurent Charest D, Lam F, Beyreuther K, Ida N, Pelech SL, Pelech SL, Reiner PB: Regulation of amyloid precursor protein catabolism involves the mitogen-activated protein kinase signal transduction pathway. J Neurosci 1997, 17:9415-9422

49. Sweatt JD: Mitogen-activated protein kinases in synaptic plasticity and memory. Curr Opin Neurobiol 2004, 14:311-317

50. Melnikova IN, Gardner PD: The signal transduction pathway underlying ion channel gene regulation by SP1-C-Jun interactions. J Biol Chem 2001, 276:19040-19045

51. Si J, Mei L: ERK MAP kinase activation is required for acetylcholine receptor inducing activity-induced increase in all five acetylcholine receptor subunit mRNAs as well as synapse-specific expression of acetylcholine receptor epsilon-transgene. Brain Res Mol Brain Res 1999, 67:18-27 